\title{
Surface soil factors and soil characteristics in geo-physical milieu of Kebbi State Nigeria
}

\author{
Suleiman Usman*
}

Department of Soil Science, Faculty of Agriculture, Federal University Dutse (FUD), Jigawa State, Nigeria

\begin{abstract}
Soil factors and surface soil characteristics are important components of agricultural environment. They support surface and subsurface soils to perform many functions to agriculture and economic human developments. Understanding these factors would aid to the recognition of the values that our soil and land offered to humanity. It is therefore, aim of this study to visualise and examine the soil factors and surface soil characteristics in Kebbi State Nigeria. An Integrated Surface Soil Approach (ISSA) was used in the classification and description of soil environment in the study region. The factors constituted in the ISSA are important components of soil science that theories and practice(s) noted to provide ideas on how soil environment functioned. The results indicate that the surface soil environments around Arewa, Argungu, Augie, Birnin Kebbi and Dandi are physically familiar with the following surface soil characteristics: bad-lands, blown-out-lands, cirque-lands, fertile-lands, gullied-lands, miscellaneous and rock-outcrops.The major soil factors observed hat played an important role in surface soil manipulations and soil formation are alluvial, colluvial, fluvial and lacustrine; ant, earthworms and termite; and various forms of surface relief supported by temperature, rainfall, relative humidity and wind. Overall, the surface soil environment of the region was describe according to their physical appearance into fadama clay soils, fadama clay-loam soils, dryland sandy soils, dryland sandy-loam soils, dryland stony soils and organic-mineral soils.
\end{abstract}

Accepted : 08.02.2016

Keywords: Soil factors, soil characteristics, assessment

(C) 2016 Federation of Eurasian Soil Science Societies. All rights reserved

\section{Introduction}

Soil science has been considered as an applied science that focussed on improving the understanding of soils and how they function (Thompson and Rimmer, 2008). It is one of the objectives of this science to generate soil information that is useful in the understanding of the true nature and properties of soil (FAO, 2006). This information has been considered as part of sustainable agriculture and human development in the $21^{\text {st }}$ Century (DESA, 2013).Therefore, the future of soil science emphasise the need to integrate ideas so as to obtain necessary soil information which could be use in many aspects of agriculture and sustainable economic development (Hartemink, 2006). Integrated idea through field assessment has been reported to provide adequate knowledge, detail information and overall insight tothe understanding of many important components of soil environment (Olson, 1981). The question here is 'what factors will be considered to achieve the need of soil science?'. Sometimes, answer to this type of question could be difficult primarily due to the fact that many issues and research interests are involved, although weights are always given to the

\footnotetext{
${ }^{*}$ Corresponding author.

Department of Soil Science, Faculty of Agriculture, Federal University Dutse (FUD), Jigawa State, Nigeria

Tel.: +2347034233241

E-mail address: labboallugu@yahoo.com

e-ISSN: 2147-4249 DOI: http://dx.doi.org/10.18393/ejss.2016.3.209-220
} 
objectives outline in a particular study. And for this, this study lays its emphasis on soil forming factors and surface soil characteristics. Information on these factors is very limited and scarce in the study region (KARDA, 1997; Usman, 2007).

The potential benefits of gathering information on surface soil characteristics and soil factors in the region is largely related to the need for informed priority to improve soil quality and environmental surroundings for diverse crop productions (Hartemink, 2006). Unfortunately, the ways of collection and management of the soil information in the study regionare not able to gather the information required for the proper management of surface soil quality. Accurate soil information about the current status of surface soil characteristic and soil factors is critical in achieving the goals of sustainable agriculture in the $211^{\text {st }}$ Century (DESA, 2013). Without proper assessments of the important soil components such as surface characteristics, soil factors and land use activities, knowledge of managing soils is almost unfeasible. Without clear and sound approach, adequate and reliable soil information is unpractical. And, without an international field guides such as FAO guidelines for soil description (FAO, 2006), understanding the classes of each soil characteristics and soil factor is impossible. Therefore, it can be justified that the need for soil assessment in the study region is vital to efficient soil management and environmental conservation (Usman, 2007). Thus, the objective of the study was to assess and discuss the major classes and characteristics of surface soil features and soil factors around Arewa, Argungu, Augie, Birnin Kebbi and Dandi areas of Kebbi State, Nigeria.

\section{Material and Methods}

\section{Study region}

Kebbi State is located geographically in the north-western part of Nigeria in sub-Saharan West African region (Figure 1). The State has a total land area of $36,229 \mathrm{~km}^{2}$ of which $12,600 \mathrm{~km}^{2}$ is under cultivated within the latitude $10^{\circ} 30^{\circ} 5^{\prime} \mathrm{N}$ and longitude $3.5^{\circ}$ and $6^{\circ}$ E (KARDA, 1997). Socially and culturally, the State has been dominated by Hausa-Fulani who depend fully on crop production, cattle rearing, fishing and mining. Their population is believed to bearound 3, 630, 9313 people according to National Population Commission of Nigeria Kebbi State chapter (NPCN-KB, 2007). The land is quite important resource to million people in the State and is been utilized for many purposes - cropping, irrigation, grazing among others.

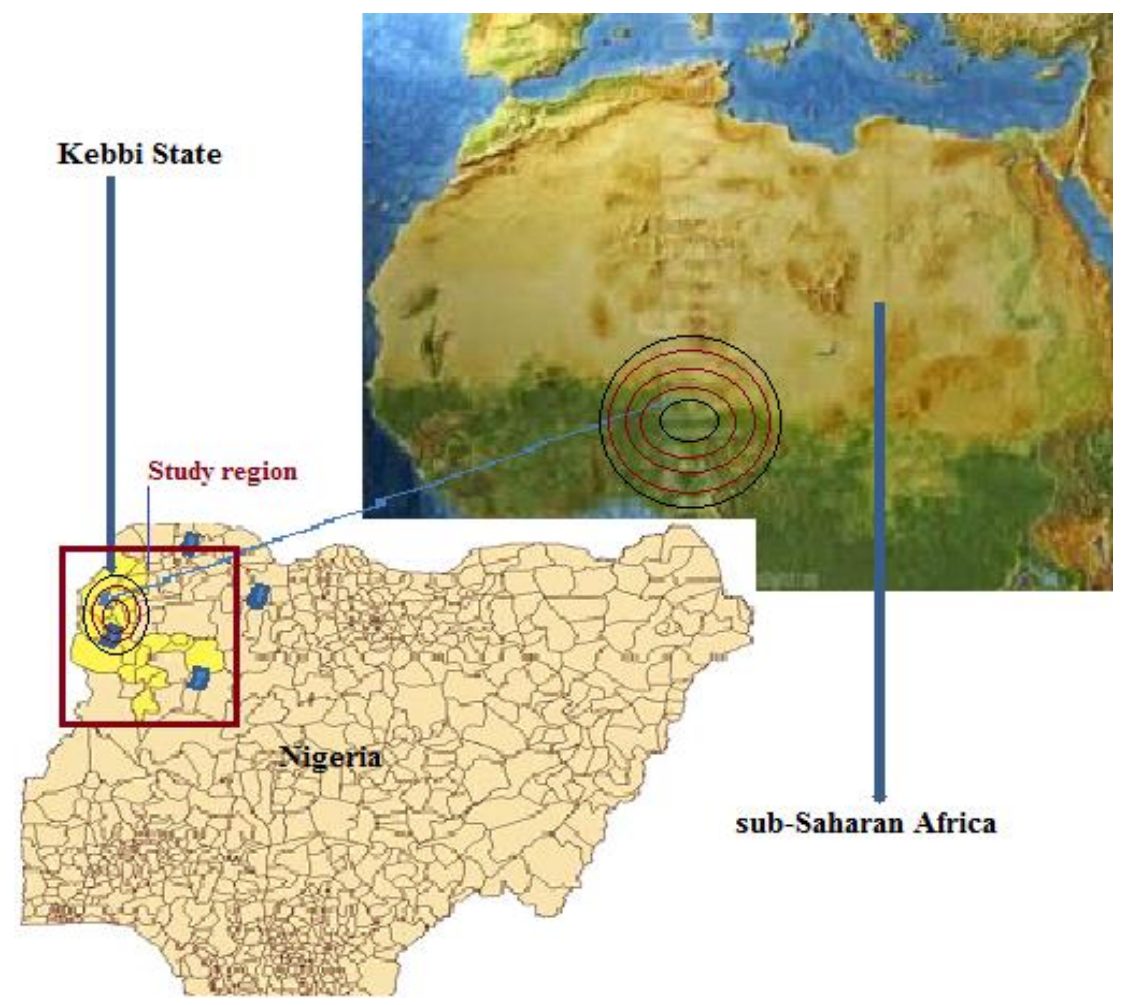

Figure 1. Location map of the study region from sub-Saharan Africa. The concentric ovals at the two parts of the map depicted the position of Nigeria and Kebbi State on the sub-Saharan African's map and Nigeria's map, accordingly. The yellow area at the map of Nigeria shows the position of the study area and the blue spots show the sites of the bordering states of Sokoto, Zamfara and Niger, consequently. 


\section{Field visit exercise}

Field visit exercise was aimlessly carried out on 74 different sites between 2009 and 2011 around Arewa, Argungu, Augie, Birnin Kebbi and Dandi local government areas of Kebbi State (Figure 2). These sites were considered because of their relevant to crop production in the State. During the visit, soil factors (parent materials, organisms, topography) and surface soil characteristics were assessed and classified, accordingly. It is important to mention that priority was only given to those soil classes, which occur more often withinthe 74 areas visited. Guidelines of soil assessment by the FAO (2006), USDA-NRCS (2002) and FAOSWALIM (2007) were employed as complete guides in the field.

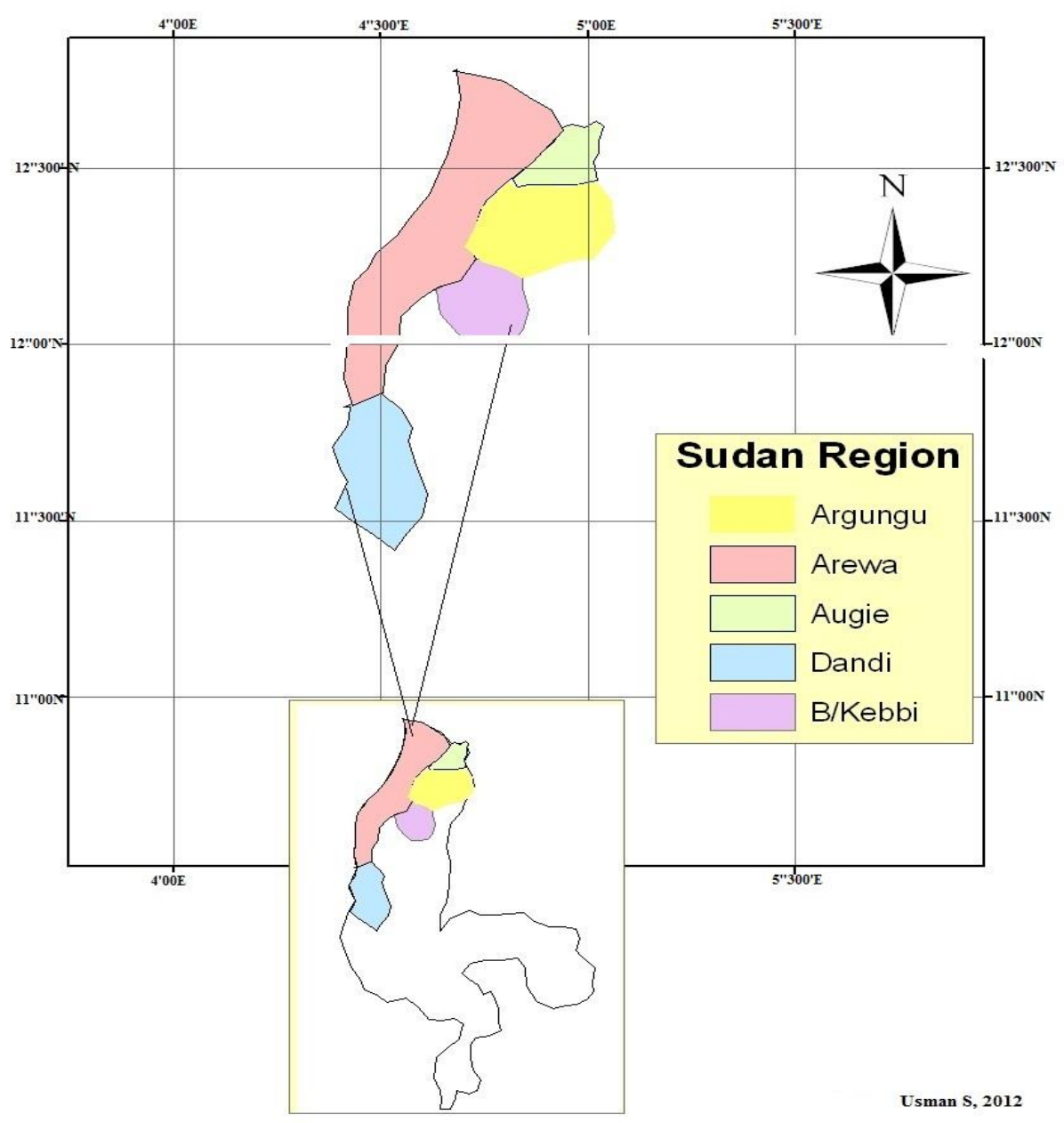

Figure 2. Map of the study sites

\section{Soils and their geographical distributions around the 74 sites visited}

The major surface soil types around the 74 sites visited in the study region are characterised as Aridisols (USDA soil order), Calcisols (FAO soil order) and Vertisols (FAO-USDA soil order) (Usman, 2013a).Aridisols and Calcisols are dryland soils described as well-drained, low organic matter, low water holding capacity and up-and-down undulating landform (Yalwa, 2008). These soils are believed to have been formed many years ago under aridity and sand dunes of sub-Saharan desert (Ahn, 1970). Geographically, they are distributed uniformly as sands, mineral stones and limestone particles covering large areas of land (Usman, 2007). The vertisols on the other hand, is a fadama soil that has been attributed with cracks during the dry season, shrink and swelling due to high clay content (Usman, 2013a).

\section{Approach used}

In order to facilitate acquisition of relevant primary information needed for this study, an Integrated Surface Soil Approach (ISSA) was designed and used from 2009 to 2011. The factors constituted in this approach were in line with the information presented in FAO Guideline for soil descriptions (FAO, 2006), Somalia Field Survey Manual (FAO-SWALIM, 2007) as well as Soils and the environment: A guide to soil surveys and their applications (Olson, 1981). 


\section{Definition of the approach}

Integrated Surface Soil Approach (ISSA) is considered as direct method of visual and digital assessments of geo-physical surface soil conditions within a scope of various ideas, skills and knowledge on factors that could potentially explain the natural surface conditions of soil environment. The factors constituted in the ISSA are important components of soil science that theories and practice(s) noted to develop trust in the understanding of the overall image of soil environment (Olson, 1981; Jenney, 1994; Usman, 2013b). The concept of the approach is depicted in Figure 3.

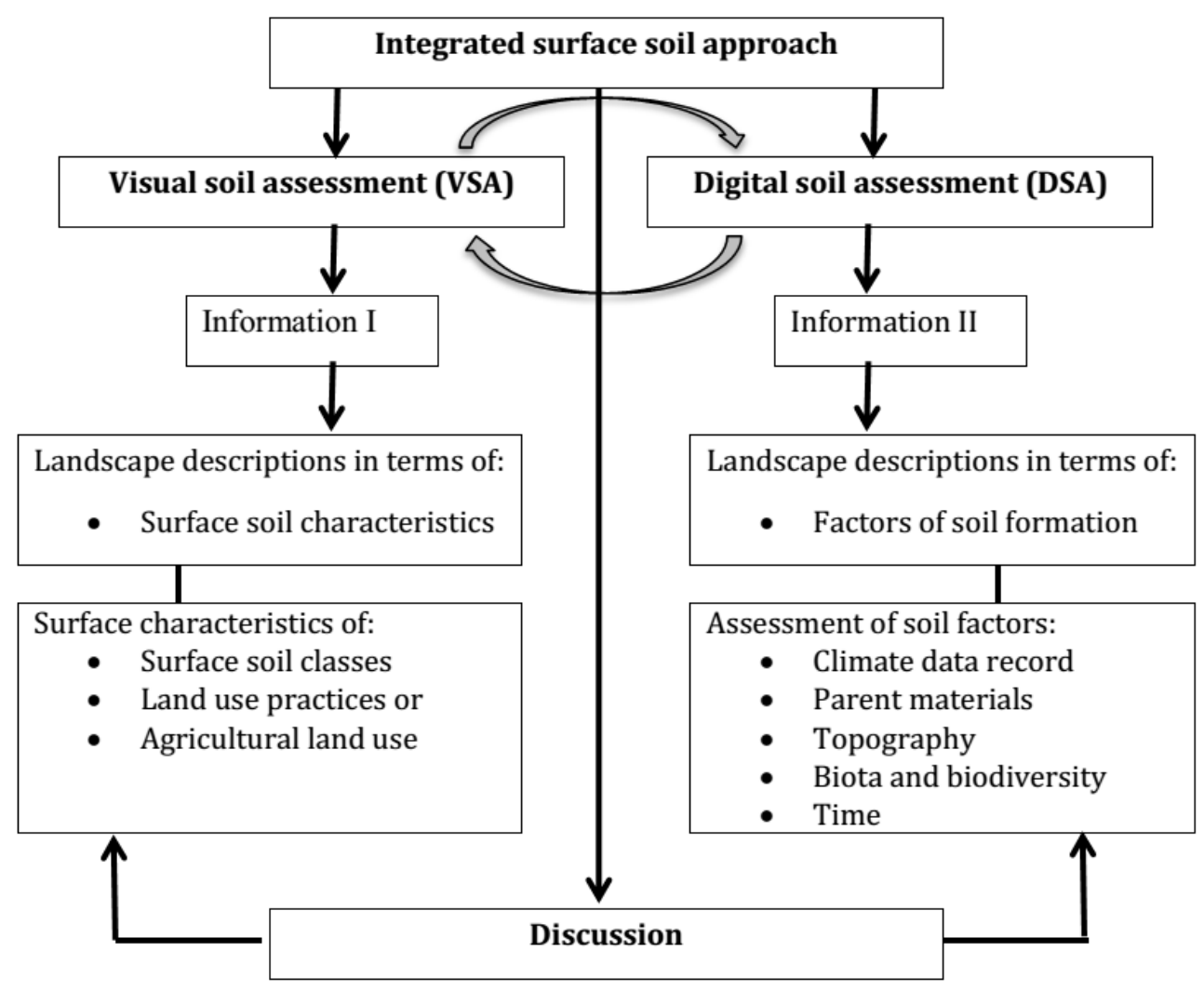

Figure 3. Integrated Surface Soil Approach (ISSA)

Figure 3 describes the conceptual framework of the ISSA. The approach has two independent components: VSA and DSA. However, the two arrows between VSA and DSA provide linkages that help to understand the current status of the surface soil components intended to assess and visualise in the study area. These linkages served as meansto record the results of the assessment together with some examples of the images of surface soil characteristics (Information I) and soil formation factors (Information II). Finally, the overall results were discussed according to the information obtained under VSA and DSA tallied with the surface soil characteristics and factors of soil formation of the study region.

\section{Digital Soil Assessment (DSA)}

The DSA was adapted to provide an overview of the true picture of surface soil characteristics and soil factors in the study region, and the concept is depicted in Figure 4. Simple procedure of photograph using Cyber-shot DSC-W510 (12.1 mega pixels) SONY camera was used in the field to take records of cloud as related to rainfall and temperature, parent materials, presence of soil organisms, characteristics of topography and land use as related to landform 's formation of the study region.

\section{Visual Soil Assessment (VSA)}

The VSA was used to evaluate parent materials, organisms, topography and those surface soil characteristics, which are visible and can be assessed directly by the naked eye primarily to explain the current status of surface soil in the study region. This type of assessment was considered important in assessing the surface soil properties, which are capable of changing as a result ofdiverse land use practices (FA0, 2008; Soil Survey Staff, 2010). In addition, previous climate data for rainfall, temperature, wind speed and relative humidityas well as the dynamic formation of the atmosphere were considered as preliminary information to further understand the physical milieu of the region. 


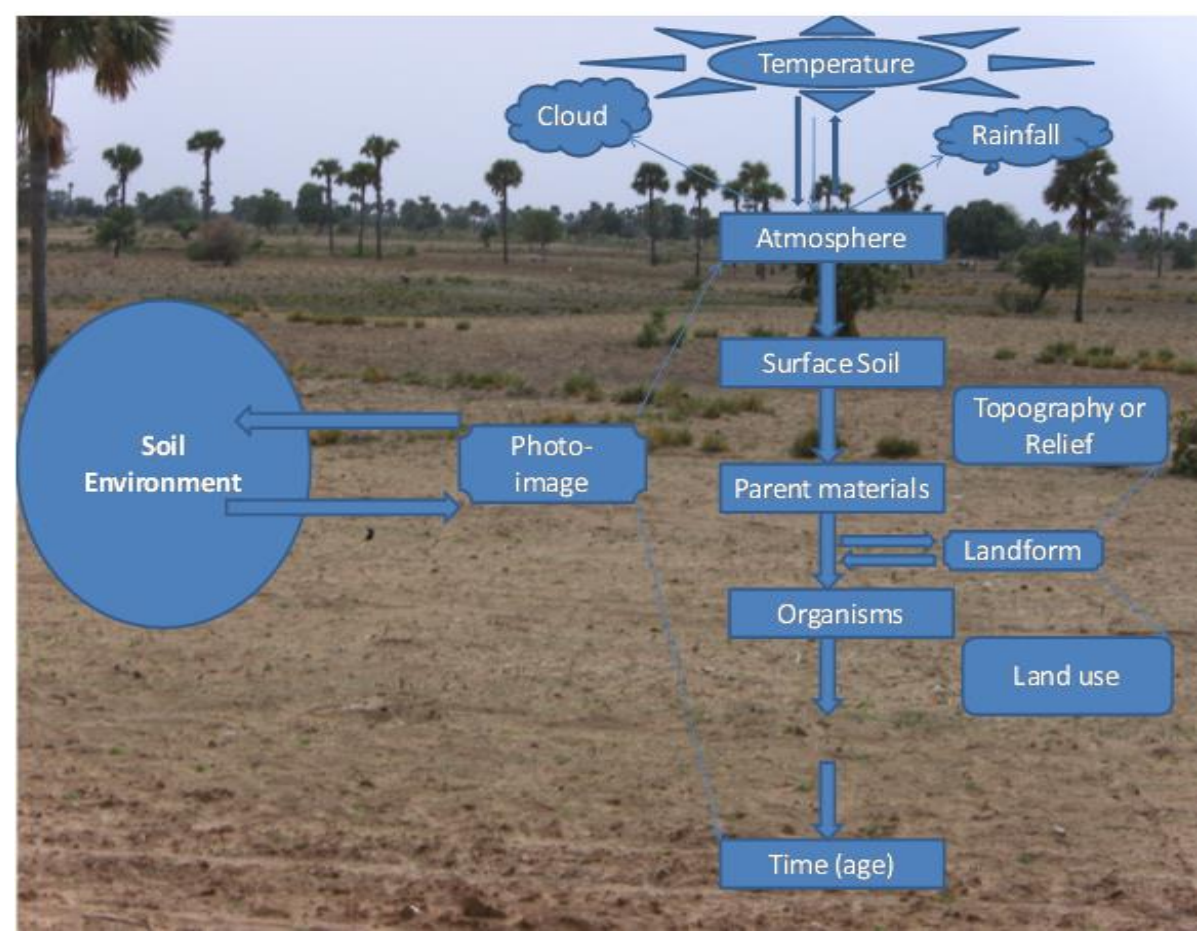

Figure 4. Digital Soil Assessment (DSA). Arrows at the top indicate the relationship between the three components of atmosphere (i.e. temperature, rainfall and cloud) considered in this assessment. Similarly, arrows at the middle indicate the relationship between soil factors, land and land use at the surface soil environment.

\section{Results and Discussion}

\section{Soil factors}

Soil factors are: climate + parent materials + topography + biota + time (Jenney, 1994). The survey on these factors in the study region is discussed below.

\section{Climate}

In order to understand the climate condition of the study region, four factors were considered namely rainfall, temperature, relative humidity and wind speed. Physically, these factors are influence by aridity, poor vegetation cover and temperatures of annual and daily fluctuations as a result of periodic energy input of the sun (Yalwa, 2008). According to local meteorological data record in the region, the annual rainfall is variable and declining, it is $600 \mathrm{~mm}$ to $875 \mathrm{~mm}$, and on average $650 \mathrm{~mm}$ during the period 1995 to 2010 . Monthly temperature throughout the year falls between $25^{\circ} \mathrm{C}$ and $45^{\circ} \mathrm{C}$. The relative humidity also varies slightly, being around $50 \%$ to $80 \%$ during the rainy season and decreased to low as $14 \%$ in dry period. The major winds occur around Decembers and January with an average wind speed of up to $18 \mathrm{~m} / \mathrm{s}$. This clearly indicates that the region has a tropical weather conditions and can be characterised into three seasons, namely: rainy, dry and hot. Rainy (wet) season starts normally from May/June to September/October, and dry season starts from December to early April whereas hot season begins in April and lasted in May as noted between 2009 and 2011. Thus, the atmospheric sky condition in the study region can be explained according to the physical nature of the sky in rainy season (Figure 5).

Generally, this physical nature of the atmospheric sky condition in the region can be grouped into four dynamic formations: the clear sky, the bright sky, the dust sky, and the cloudy sky. The clear sky normally occurs from mid-October and March to early April usually brings stable atmospheric conditions with no cloud, no dust. During the months of December and early January, the sky experiences dust condition making atmosphere unstable due to accumulation of million dust particles overlooking the atmospheric surface environment. The sky become bright mostly in the mid of April through May and June causing rapid temperature increases as a result of direct solar heat radiation to the surface soils (temperature is from 30 $45^{\circ} \mathrm{C}$ ). Cloudsky happens during the rainy season when the atmosphere saturated by air causing different forms of clouds with different shapes, sizes and colours (Figure 5). 

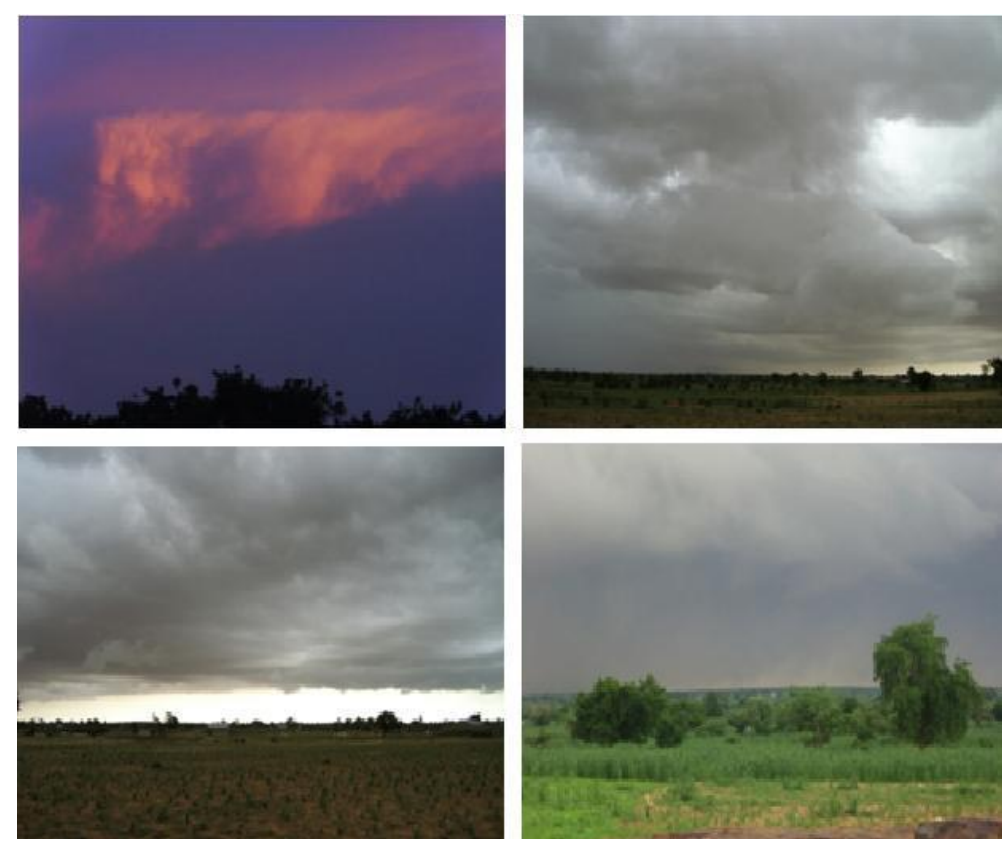

\section{Parent materials}

Figure 5. Physical condition of atmospheric sky in the study region

Table 1 gives the summary of the major classes of parent materials in the study region. These parent materials are grouped according to origin of their formations, noted from igneous to metamorphic and finally to consolidated and unconsolidated classes.

Table 1. Major classes of parent materials in the study region

\begin{tabular}{|c|c|c|c|}
\hline Major class $^{1}$ & Group ${ }^{1}$ & Type $^{1}$ & Remarks $^{2}$ \\
\hline Igneous rock & Basic & $\begin{array}{l}\text { Dolerite } \\
\text { Ironstone }\end{array}$ & $\begin{array}{l}\text { Not good for agriculture but can be used in the } \\
\text { context of soil protection }\end{array}$ \\
\hline Metamorphic rock & Basic & $\begin{array}{l}\text { Phyllite } \\
\text { (Peltic-R) } \\
\text { limestone (marble) }\end{array}$ & Good for building and water ways (drainage) \\
\hline $\begin{array}{l}\text { Sedimentary rock } \\
\text { (Consolidated) }\end{array}$ & $\begin{array}{l}\text { Clastic } \\
\text { sediments }\end{array}$ & $\begin{array}{l}\text { Sandstone silt, } \\
\text { clay and clay-stone } \\
\text { Limestone } \\
\text { Sand } \\
\text { Silt }\end{array}$ & $\begin{array}{l}\text { Require well-sustainable management practices for } \\
\text { agricultural improvement }\end{array}$ \\
\hline $\begin{array}{l}\text { Sedimentary rock } \\
\text { (Unconsolidated) }\end{array}$ & $\begin{array}{l}\text { Carbonate, } \\
\text { Fluvial } \\
\text { Colluvial } \\
\text { Alluvial } \\
\text { Lacstrine } \\
\text { Estuarine }\end{array}$ & $\begin{array}{l}\text { Clay } \\
\text { Loam } \\
\text { Clay } \\
\text { Clay-loam } \\
\text { Sand } \\
\text { Silt } \\
\text { Slope deposits }\end{array}$ & $\begin{array}{l}\text { Good for wide range agricultural activities: cereal } \\
\text { farming, irrigation and horticultural cropping } \\
\text { system; still required regular soil management } \\
\text { Practices. }\end{array}$ \\
\hline
\end{tabular}

Lithologically, the surface soil parent materials in the study region vary significantly probably due to landform variations and differences in land use activities. In dryland sites, large portion of the land has been covered by sedimentary sand and silt particles of which are clastic and carbonated anthropogenic sediments by their physical appearances. And, in fadama sites, the land is covered by clay and clay-silt/loam particles, which is believed to have been originated from alluvial, colluvial, fluvial and lacustrine deposited particles (Table 1). Typical examples of these parent particles are depicted in Figure 6 and 7.

Physically, it is believe that the result of diverse agricultural activities has caused many surface soil changes, and probably led to the continuous formation of other soil particles (Brady and Weil, 2007). These particles are classified into: fluvial such as pure sand, gravel and clay; alluvial such as clay, clay loam; lacustrine such as sand-loam, silt and clay; estuarine such as fine sand and clay particles and many others (Table 1; Figure 
7). However, the dynamic changes on these parent particles could be related to factors such as the surface climate, deforestation, bush burning, soil erosion, drought and addition of organic materialsthat contribute significantly to soil formation (Jenney, 1994).

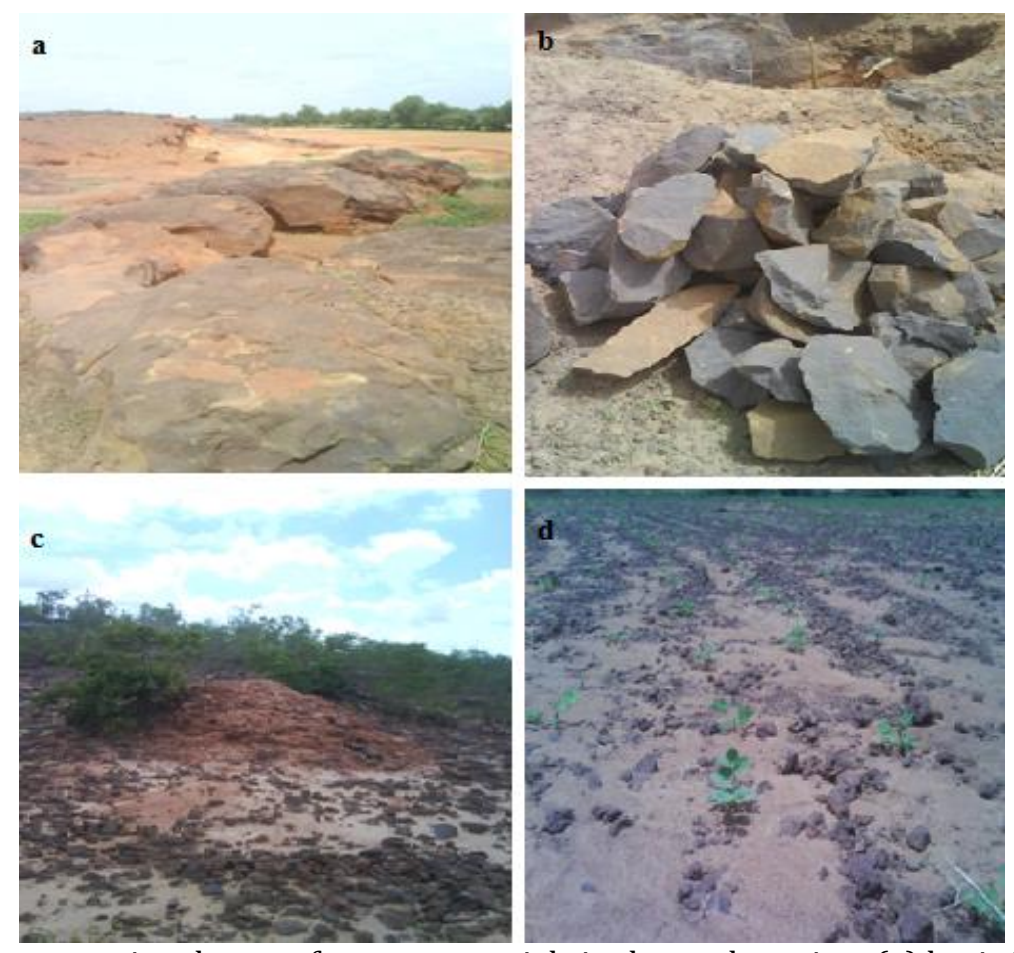

Figure 6. Examples of some major classes of parent materials in the study region: (a) basic igneous rock, (b) peltic metamorphic rock, (c) fluvial Sedimentary rock [unconsolidated sand and gravel] and (d) clastic sedimentary rock [consolidated sandstone]

Characteristically, the surface agricultural soils of the study region can be categorised according to their current parent particles into - fadama clay soils, fadama alluvial soils, dryland sandy to sandy-loam soils, dryland stony soils, and organic-mineral upland soils.

\section{Topography}

Table 2 outlines the major classes of surface topography in the study region. The shapes and positions of each class have been characterised, accordingly. Physically, some classes are flat and level while others are sloppy, up-and-down and gently-slope depending on the nature and condition of their formation in the field.

Table 2. Major classes of topography in the study region

\begin{tabular}{llll}
\hline Class $^{\mathbf{1}}$ & Shape $^{\mathbf{1}}$ & Position $^{\mathbf{1}}$ & Remarks $^{\mathbf{2}}$ \\
\hline Flat & Straight & Summit & Visible: $1 \mathrm{~m}-100 \mathrm{~m}$ or $<$ \\
Level & Straight & Shoulder & Visible: $1 \mathrm{~m}-30 \mathrm{~m}$ only \\
Very gentle slope & Concave & Middle & Visible but: $0.5 \mathrm{~m}$ or $>$ \\
Slopping area & Concave & Lower & Not visible: $0.0 \mathrm{~m}-0.0 \mathrm{~m}$ \\
Sloppy-site & Concave & All-over & Open milieu: visible \\
Sloppy & Linear & Back-slope & Only visible at very close \\
Flat & Shallow & All-over & Only visible at very close \\
Up-and-down & Back-slope & Partly & Visible: $1 \mathrm{~m}-300 \mathrm{~m}$ \\
Gently-slope & Contour & Middle & Visible at short distance \\
Gently-slope & Convex & Partly & Visible: $1 \mathrm{~m}-260 \mathrm{~m}$ \\
\hline
\end{tabular}

${ }^{1}$ According to USDA-NRCS (2002) guideline; ${ }^{2}$ Based on VSA in the field

The topography varied from flat to level and gentle to sloppy (Table 2). Most of the flat reliefs are straight and are visible from $1 \mathrm{~m}-100 \mathrm{~m}$. This flat sites show little or no impact of surface erosion as compare with the very gently and sloppysites as physically noted between 2009 and 2011. It is believed that there are considerable surface relief's changes particularly in the dryland sites - mainly anthropogenic human activities such as deforestation. These changes have created some major surface imbalances between soil structure, soil texture and basic parent particles. Typical examples of some major classes of topography are depicted in Figure 8. 

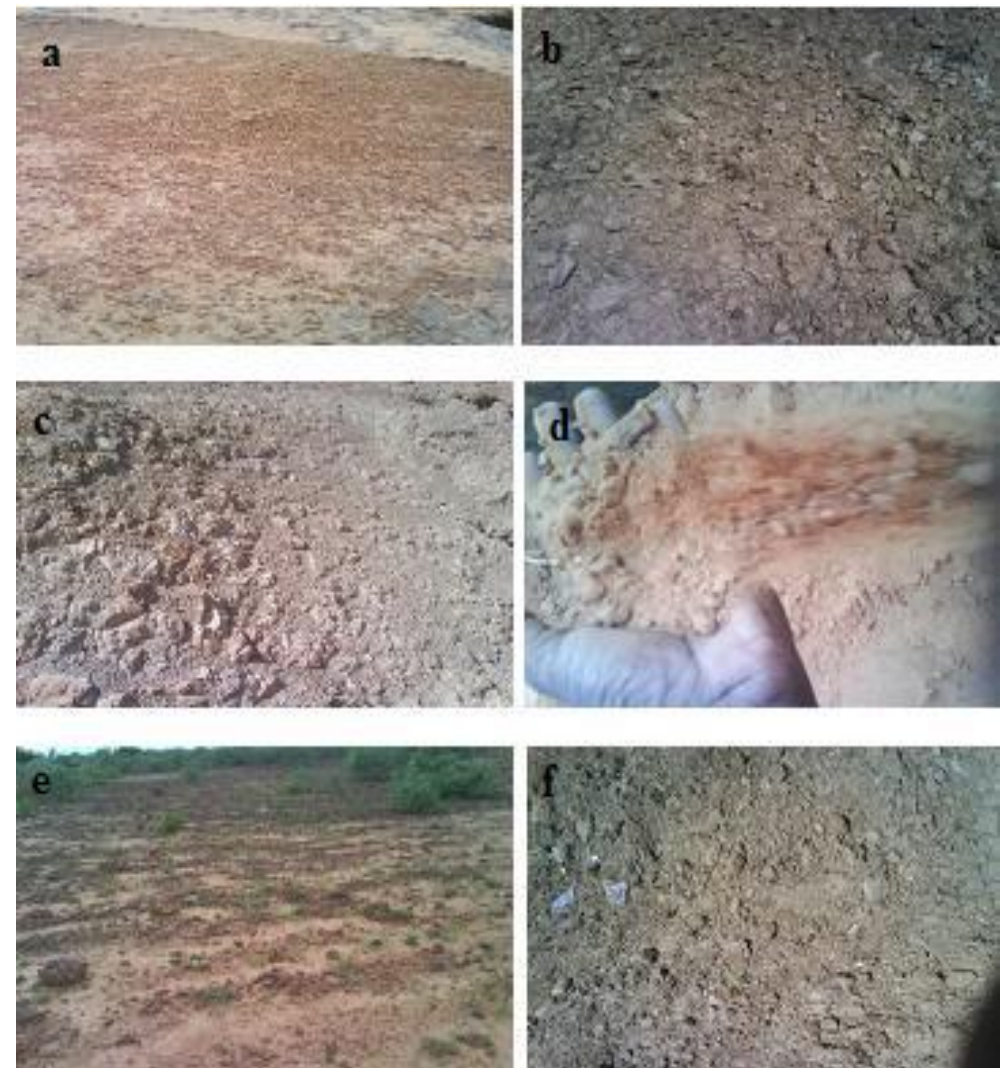

Figure 7. Examples of some major groups and types of consolidated and unconsolidated particles in the study region: (a) clastic sediments sandstone, (b) lacstrine clay soil, (c) organic limestone (carbonate), (d) lacstrine sand, (e)clastic sandstone, and (f) estuarine marine clay
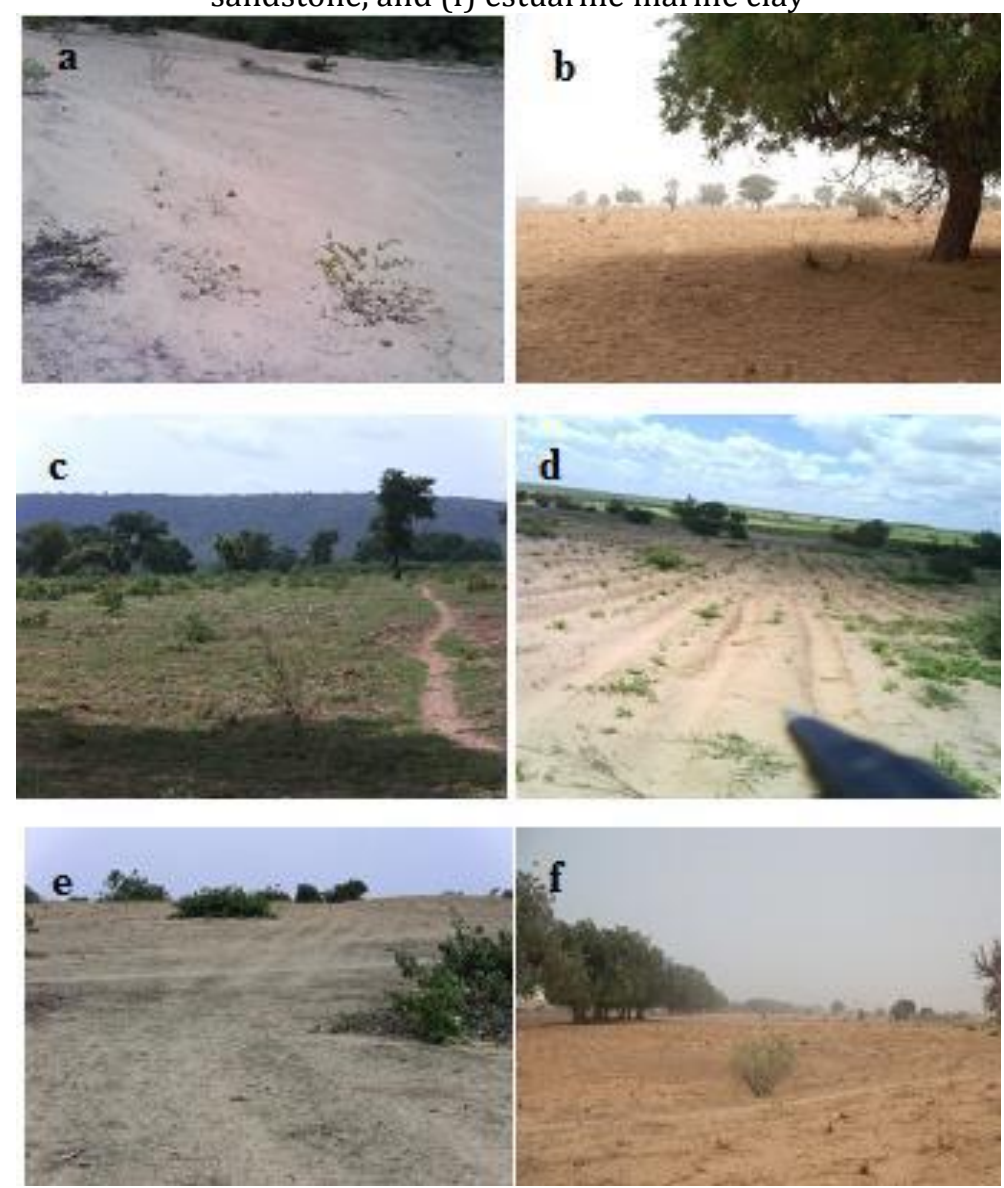

Figure 8. Examples of some major surface soil reliefs in the Sudan Savannah.(a) Very gentle slopping area, (b) Almost flat relief area, (c) Straight relief area (d) Strongly slopping area, (e) Up-and-down area, and (f) Valley area 


\section{Soil biota and biodiversity}

The major types of soil organisms observed are termites, earthworms, ants and nematodes. These organisms were physically assessed according to the nature of their presence, biodiversity or activities and appearance on/within surface soil voids. Remarkably, these organisms play important role in the breakdown and decomposition of many organic materials in soil (Ritz et al., 2010). They contribute widely in the improvement and transformation of soil quality, soil organic matter and soil nutrients availability (Brussaardet al., 2007; Li et al., 2014; Castro-Huerta et al., 2015).Typical examples of biota and their biodiversity are depicted in Figure 9.
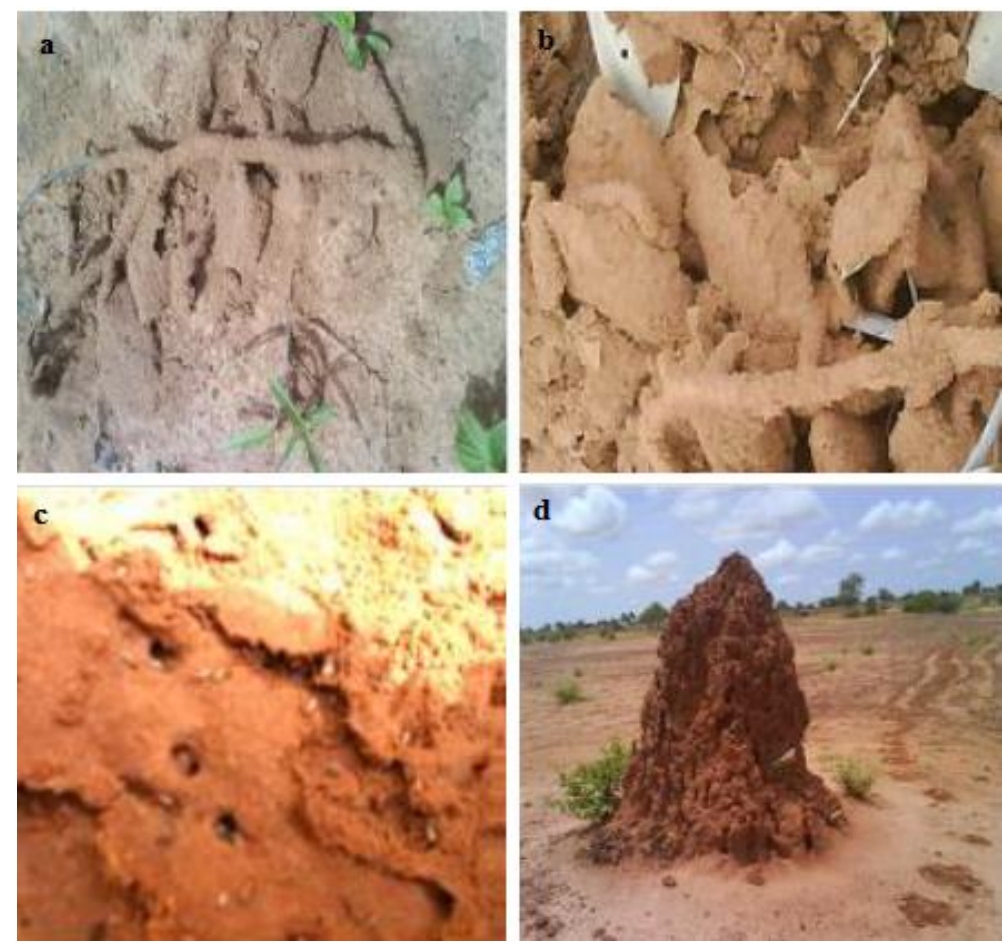

Figure 9. Some major activities of biota and their biodiversity in study region: (a), (b) and (d) indications of biological activities and (c) mobility of termite population

\section{Surface soil characteristics}

Table 3 gives the major surface characteristics in the study region.

Table 3. Classification of major surface characteristics in the study region

\begin{tabular}{|c|c|c|}
\hline Class $^{1}$ & Remarks $1^{2}$ & Remarks $2^{2}$ \\
\hline Miscellaneous & Eroded soil environment & $\begin{array}{l}\text { No vegetation, few grass, and no original surface soil } \\
\text { features }\end{array}$ \\
\hline Blown-out land & Desertification is common & Winnowing and mass movement of soil particles \\
\hline Cirque land & $\begin{array}{l}\text { Area dominated by rock with } \\
\text { cirque shapes }\end{array}$ & No trees with only few grasses \\
\hline Gullied land & $\begin{array}{l}\text { Areas with deep cut of } \mathrm{V} \text { and } \mathrm{U} \\
\text { shapes gullies }\end{array}$ & $\begin{array}{l}\text { Original surface soil parent particles have been } \\
\text { disappeared }\end{array}$ \\
\hline Rock-outcrop & Bare bedrocks areas & No space for grasses and trees \\
\hline Slickness & Fine-textured soil areas & Plant and shrubs areas \\
\hline Water & Rivers areas & Fishing and irrigation farming \\
\hline Bad land & Bad soils & No agricultural function \\
\hline
\end{tabular}

${ }^{1}$ According to FAO (2006) guideline for soil description; ${ }^{2}$ Based on VSA in the field

Physically, the most risk and poor surface characteristic in this classification are gullied land areas, which most of them are bad-lands. These areas require an engineering and well planned sustainable land management. By contrast, the rock-outcrop areas could be considered as support to surface soil, they bind soil particles and thus, minimise the risk of erosion (FAO, 2006). Water areas are important sites for irrigation and other agricultural activities in the region. Typical examples of these surface characteristics are depicted in Figure 10. 


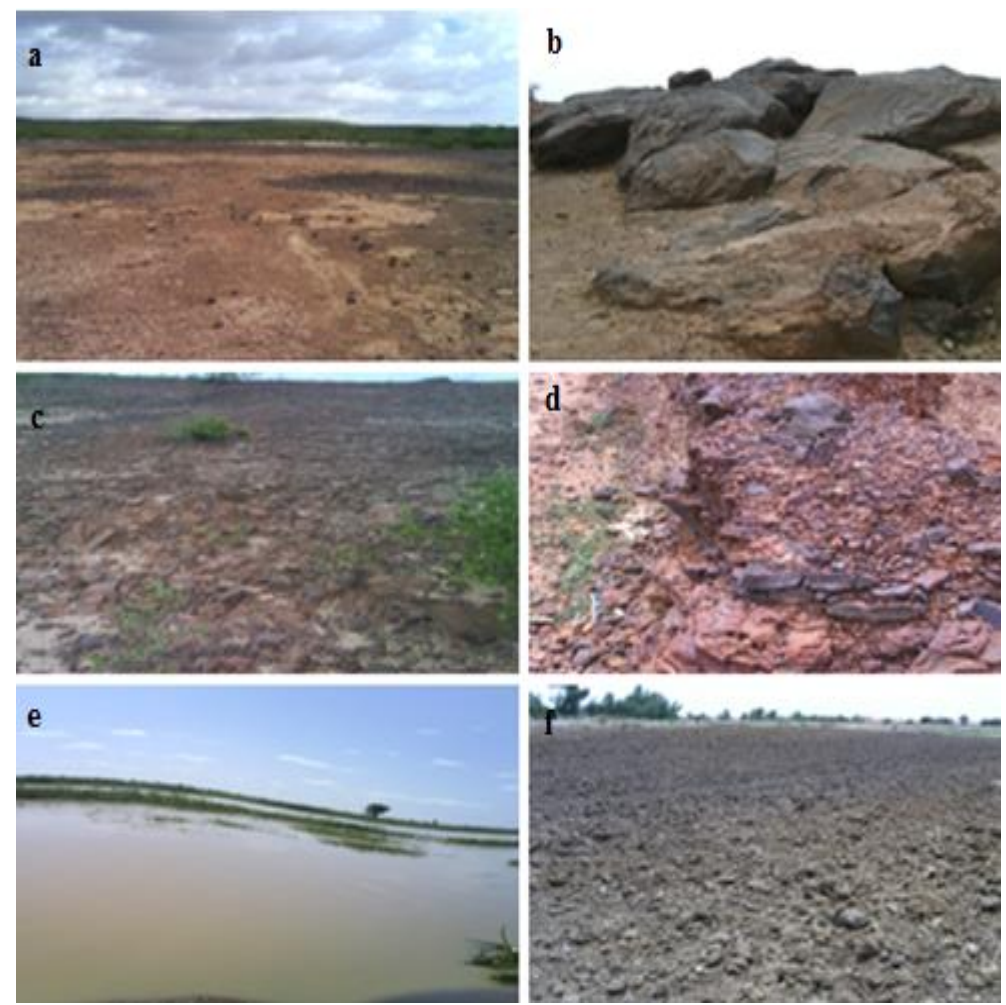

Figure 10. Examples of some major surface characteristics in the study region: (a) miscellaneous area, (b) rockoutcrop area, (c) cirque land, (d) bad land, (e) water body area, and (f) Slickness area

\section{Time}

The period of time in the formation of soil, is a factor that can be related to the historical background of human development and agricultural activities in the region. It is believe that the surface soil of the region received changes long time ago related to the human settlements in the region (e.g. Ahn, 1970).

\section{Land use activities}

Table 4 presents the major land use activities in the study region. The results conformed to other previous studies in the region (Mortimore, 1989; Baker, 2000; Usman, 2007). The typical examples are depicted in Figure 11.

Table 4. Major land use practices in study region

\begin{tabular}{|c|c|}
\hline Land use activities $^{1}$ & Remarks ${ }^{1}$ \\
\hline Agricultural land use & Agriculture is the economic development of the State. \\
\hline $\begin{array}{l}\text { Dry farming system } \\
\text { Mono-cropping }\end{array}$ & $\begin{array}{l}\text { Cereals (millet, sorghum), legumes (cowpea, ground nut) are the major crops } \\
\text { growing in dry farming system of the State. }\end{array}$ \\
\hline \multicolumn{2}{|l|}{ Inter-cropping } \\
\hline \multicolumn{2}{|l|}{ Crop rotation } \\
\hline \multicolumn{2}{|l|}{ Mixed farming } \\
\hline Fadama land use & Important land areas for rice and wide range of horticultural crops (tomato, chilli, \\
\hline Irrigation system & leaves, okra, etc). \\
\hline \multicolumn{2}{|l|}{ Sowing method } \\
\hline \multicolumn{2}{|l|}{ Horticultural } \\
\hline Orchard farming system & Plantation of mango, guava, cashew, are common. \\
\hline \multicolumn{2}{|l|}{ Fruit trees plantation } \\
\hline Pastoralistfarming system & Cattle, sheep's, goats, are the common animals under trans-human system. \\
\hline \multicolumn{2}{|l|}{ Extensive nomadic } \\
\hline \multicolumn{2}{|l|}{ Extensive non-nomadic } \\
\hline Intensive rearing & Local hens, layers and broilers. \\
\hline \multicolumn{2}{|l|}{ Poultry farming system } \\
\hline \multicolumn{2}{|l|}{ Extensive system (local) } \\
\hline Intensive (Business) & Mainly grasses and shrubs of various types. \\
\hline \multicolumn{2}{|l|}{ Grazing land use } \\
\hline Grass land area & \\
\hline
\end{tabular}

${ }^{1}$ According to the current status of agricultural sites via VSA in the field 

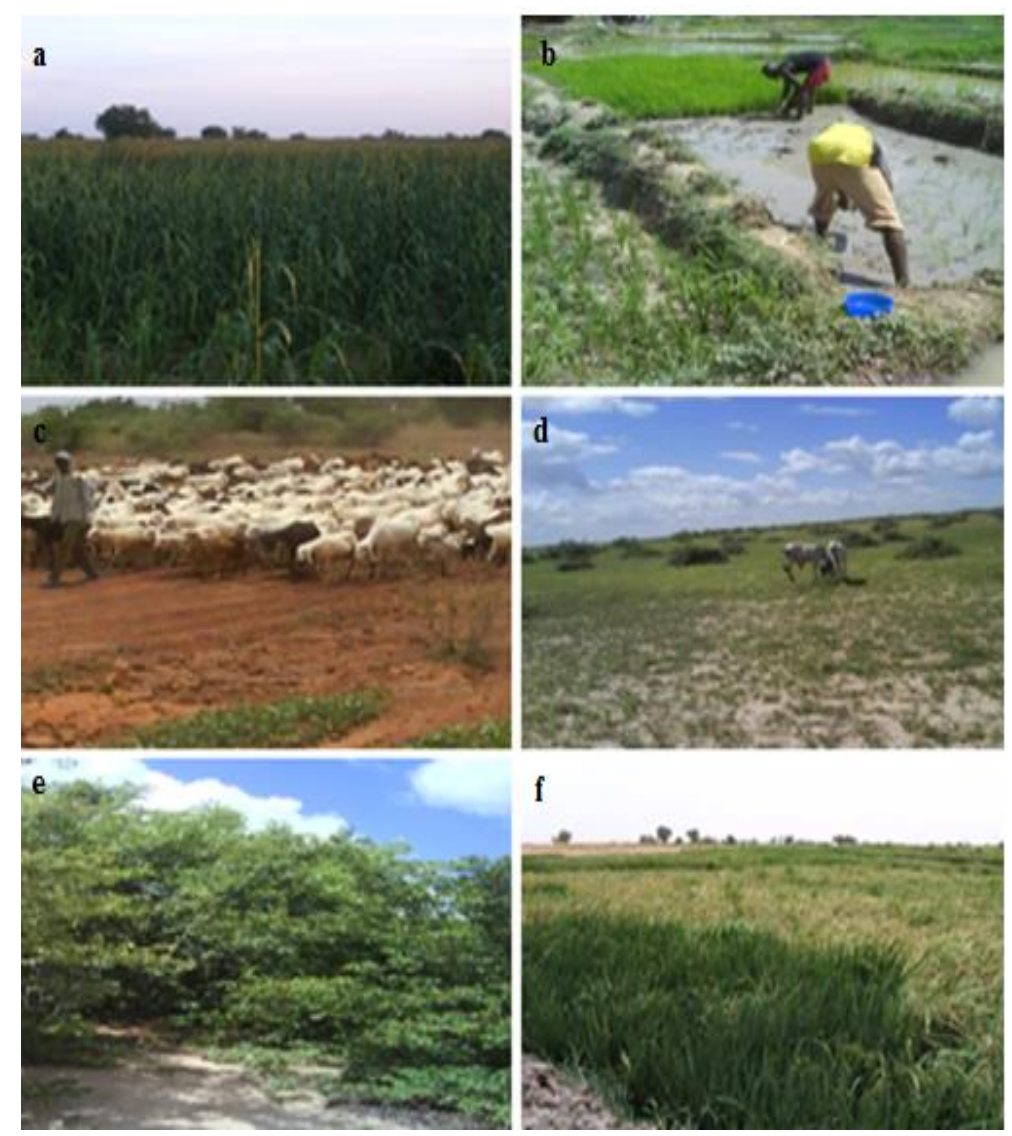

Figure 11. Examples of land use activities in the study region. (a) dry farming system (millet production), (b) irrigation system, (c) nomadic pastoralist system, (d) grazing land, (e) grazing land, and (f) fadama rice production (sawing)

\section{Conclusion}

The study captured some values of surface soil environment in the study region. Soil factors, surface soil characteristics and land use activities are covered. It has been understood that a very close and interdependent relationship had always existed between all phases of soil components in the study region. Soil parent materials and biota were found interacted with one another, adding values to soil quality and soil fertility. Also, climate factors such as rainfall, temperature, relative humidity and wind were also noted to have independently interconnected with soil particles and added values tosoil for different agricultural land use activities.

An alternative approach, as adapted in this study, would give necessary information to the local people and government in general usefully, understanding both the values of their land resources and current status of its condition related to future management and transformation. The difficulties of this approach however, are the fact that it requires time, careful observation and field visit all over the region as well as additional guidelines for environmental soil assessment. Thus, further assessment is required to determine if improvement can be made to the approach for wide use to other local environments.

\section{Acknowledgements}

This research was funded by Kebbi State government as part of research and educational development in the State. The State government is acknowledgedfor this effort. Also, I thank the Kebbi State Ministry of Education for supporting the programme, and Editors for their constructive recommendations that have helped to improve the quality of the manuscript.

\section{References}

Ahn, P.M., 1970. West African Soils. Oxford University Press. 231p.

Baker, K.M., 2000. Indigenous Land Management in West Africa: An Environmental Balancing Act. Oxford Geographical and Environment Studies. Oxford University Press. 198 p. 
Brady, N.C., Weil, R.R., 2007. Elements of the nature and properties of soil. 2nd edition. Pearson Prentice Hall Pub., Upper Saddle River, New Jersey, $614 \mathrm{p}$.

Brussaard, L., de Ruiter, P.C., Brown, G.G., 2007. Soil biodiversity for agricultural sustainability. Agriculture, Ecosystems and Environment 121(3): 233-244.

Castro-Huerta, R.A., Falco, L.B., Sandler, R.V., Coviella, C.E., 2015. Differential contribution of soil biota groups to plant litter decomposition as mediated by soil use. PeerJ 3:e826.

DESA, 2013. World economic and social survey 2013: Sustainable development challenges. department of economic and social affairs (DESA) of the United Nations Secretariat. United Nations publication,E/2013/50/Rev.1 ST/ESA/344.New York, USA.

Available at: https://sustainabledevelopment.un.org/content/documents/2843WESS2013.pdf [access date: 09.12.2015]

FAO, 2006. Guidelines for soil descriptions. $4^{\text {th }}$ edition. Food and Agricultural Organization of United Nation, Rome, Italy. Available at:http://www.fao.org/3/a-a0541e.pdf [access date: 09.12.2015]

FAO, 2008. Visual soil assessment - Field guides. Food and Agricultural Organization of United Nation, Rome, Italy. Available at:http://www.fao.org/3/a-i0007e.pdf [access date: 09.12.2015]

FAO-SWALIM, 2007. Field Survey Manual. Project Report No L-01. Somalia Water and Land Information Management in Association with European Union and FAO. pp. 70-71.

Hartemink, A.E. 2006. The future of soil science. IUSS International Union of Soil Sciences. Wageningen, The Netherland. Available at: http://www.iec.cat/mapasols/DocuInteres/PDF/Llibre07.pdf [access date: 09.12.2015]

Jenney, H., 1994. Factors of soil formation: A system of quantitative pedology. Dover Publications Inc., New York, USA. $281 \mathrm{p}$.

KARDA, 1997. Diagnostic survey report of agro-forestry and land management practices in Kebbi State. Kebbi Agricultural and Rural Development Authority (KARDA), Kebbi State, Nigeria.

Li X., Yin X., Wang Z., Fan W., 2014. Interaction between decomposing litter and soil fauna of the Betula ermanii forest floor of the Changbai Mountains, China. Canadian Journal of Forest Research 44(12):1507-1514.

NPCN-KB, 2007. 2006 National Population Census of Nigeria Report. NPCN, Kebbi State. Produced by NPC national headquarters, Abuja, Nigeria.

Olson, G.W., 1981. Soils and the environment: A guide to soil surveys and their applications. Dowden and Culver Book \& Chapman and Hall, New York and London. pp. 22-24.

Ritz, K., Harris, J., Murray, P., 2010. The role of soil biota in soil fertility and quality, and approaches to influencing soil communities to enhance delivery of these functions. Defra project code: SP1601: Sub-Project A of Defra Project SP1601: Soil Functions, Quality and Degradation - Studies in Support of the Implementation of Soil Policy.

Soil Survey Staff, 2010. Keys to soil taxonomy. $11^{\text {th }}$ edition. United States Department of Agriculture (USDA), Natural Resources Conservation Service, Washington DC, USA. 337 p.

Thompson, T.R.E., Rimmer, D.L., 2008. Soil science and policy: Issues behind the need for better land use planning and soil management. In: Proceeding of the SAC and SEPA Biennial Conference. Crighton, K.,Audsley, R. (Eds.). 26-27 March 2008, Edinburgh, UK, pp. 3-11.

USDA-NRCS, 2002. Field Book for Describing and Sampling Soils, Version 2.0. United States Department of Agriculture (USDA), Natural Resources Conservation Service. National Soil Survey Center, Lincoln, NE, USA.

Usman S., 2007. Sustainable soil management of the dryland soils of northern Nigeria. GRIN Publishing GmbH, Munich, Germany. 114 p. Available at: http://www.grin.com/en/e-book/172291/sustainable-soil-management-ofthedryland-soils-in-northern-nigeria [access date: 09.12.2015]

Usman, S., 2013a. Visual assessment and classification of surface soil types in dryland and fadama areas of Kebbi State, Nigeria. International Journal of Development Research 3 (11): 141 - 146.

Usman, S., 2013b. Understanding soils: Environment and properties under agricultural conditions. America Star Books, Baltimore, USA. $158 \mathrm{p}$.

Yalwa, S.A., 2008. Broad scale vegetation change assessment across Nigeria from coarse special and high temporal resolution AVHRR Data. Cuvillier Verlag, Gottingen Nonnenoteg, Gottinen. pp. 60 - 61. 